\title{
DYNAMIC IDEOLOGY OF TRADITIONALITY IN DEVELOPING HOLY PLACES AT HINDUS FAMILY IN CAKRANEGARA TERRITORY MATARAM CITY
}

\author{
I Wayan Ardhi Wirawan \\ STAHN Mataram \\ iwayanardhiwirawan@gmail.com
}

\begin{tabular}{|l|l|}
\hline Riwayat Jurnal \\
Artikel diterima: 1 Januari 2020 \\
Artikel direvisi: 3 Mei 2020 \\
Artikel disetujui: 28 Juni 2020 \\
\hline Keyword: & $\begin{array}{l}\text { Abstract } \\
\text { dynamics } \\
\text { traditionality ideology } \\
\text { holy place } \\
\text { Hindu families } \\
\text { in building holy place among Hindus families in Cakranegara } \\
\text { territory, Mataram city. This research was designed in the type of } \\
\text { interpretative qualitative research using a case study model. Data } \\
\text { collection techniques through observation, interviews, and } \\
\text { documentation. Data were analyzed through the stages of } \\
\text { classification, reduction, and interpretation. Tri angulation } \\
\text { techniques, both tri angulation methods and tri angulation of data } \\
\text { sources were used to check the validity of the data. The results } \\
\text { showed that the dynamics of traditional ideology in building holy } \\
\text { place of Hindu families had been indicated by transformation of } \\
\text { cultural traditions at Hinduism practices in four dimensions. } \\
\text { First, the position of placing the holy place later no longer applies } \\
\text { traditional concepts in a rigid and standard manner. Second, with } \\
\text { regard to the spatial size in the construction of holy place in at } \\
\text { Hindu families is no longer fixed on the size of the spatial layout } \\
\text { that is traditionally applied but adjusted to the situation and } \\
\text { condition of karang paumahan (area of home). Third, the form of } \\
\text { holy has adapted to the inclusion of external culture. Fourth, the } \\
\text { number of pelinggih (holiy place buildings) tends to decrease, } \\
\text { especially in the relatively small area of home. }\end{array}$ \\
\hline
\end{tabular}

\section{Introduction}

The dynamics in the sosioreligiusitas order is a necessity as the implications of cultural adaptation. This phenomenon is synergized with the expression Triguna (2003: 2) which states that the environment adapted by humans continues to change, so that in the adaptation effort humans continue to follow, observe, and interpret 
various symptoms and changes that occur in the environment dynamically. Humans who assume ways to adjust and give meaning that were previously less relevant, then there is a tendency that way will be replaced by ways that are assumed to be more appropriate after going through the mechanism of understanding and socialization.

Synergizing with cultural adaptation, the dynamics in the administration of religion in social spaces provide opportunities for the creation of contextual reinterpretations of religious teachings. The reinterpretation is intended to open the process of re-interpretation of the elements in religious practice so that they synergize with the progress of human civilization. The reinterpretation is parallel with the orthopraxic concept put forward by Andang (1998: 71), which is an attempt to translate religion into an emancipative effort, an effort that respects all forms of life with its complexity. Religion needs to continue to maintain the ethos of searching for human transcendental meaning but without forgetting its praxis estuary.

The dynamics in religious practice are systemic in a number of cases, namely opening up space for the transformation process in other components. The dynamics in the realm of religious practice is also determined by changes in the social system. Referring to Sanderson (2003: 64-65) which states that changes that occur in one component in the social system cause changes in other components. Changes that occur include both the socio-cultural system and the separate components of the system. The reality, what usually happens is that change starts from one component and this change causes changes to other components. In line with Sanderson's concept, changes in the social component tend to cause dynamics in a number of aspects amidst religious practice.

Regarding the above phenomenon, one case involving social change has a contribution to contribute to the dynamics in the social-religious order as it emerged among Hindu followers in Cakranegara territory area, Mataram City, West Nusa Tenggara Province. This phenomenon is indicated by the transformation process in some symbolic dimensions of Hindu religious practice. The dynamics that occur in symbolic aspects as a cultural adaptation such as setting the spatial dimension of a sacred place in a Hindu families. The dynamics relating to the spatial dimension in determining and building the area of holy place in a number of Hindu families in these locations experience contextually reinterpretation.

The construction of a sacred area within the Hindu families traditionally refers to sastra drsta (literary tradition) using a spatial measurement with reference to the asta kosala kosali and aalso asta bhumi. In another dimension in establishing the area of Hindu holy place in the Hindus family, the direction of the compass is positioned as part of an evaluative symbol concerning moral judgment. Evaluative symbols are positioned in building the area of holy sites such as kaja (north) and 
kangin (east) or a combination of both, namely kaja kangin (northeast). In the teachings of Hinduism it is contained in the belief that the direction of the kaja (north) which positions the location of the mountain as a symbol of purity, namely the stana of the gods, especially Lord Shiva. The direction of kangin (east) as the position of the sanctuary area is based on the belief that the east is the position of the rising sun, that is, as a symbol of Surya or Lord Shiva Raditya. The direction of kaja kangin (northeast) is a combination of the two which is also believed to have a vibration of holiness as an evaluative symbol in placing the area of a sacred place within the Hindu family.

The influx of the influence of modernization and the ideology of a group of spirituality followers of the evaluative arrangement of symbols in developing the area of a holy place in a Hindu family environment experiences dynamics. The effect of modernization which has implications for the commodification of residential places makes the family home area has a very high economic value. Based on this phenomenon in building the area of the holy place in the Hindu families is very concerned about the spatial conditions of settlements. Literary guidelines relating to the construction of family holy place in the form of measurements that refer to the kosali asta kosala manuscript and also manuscript of asta dewa are no longer fully applied. Standardization of the direction of the Kaja (North) and Kangin (East) directions or the combination of them, Kajakangin (Northeast) is no longer the standard that guidelines must use. The influence of the ideology of the group of spirituality contributes to the form of a holy place in the Hindus family that does not all use the traditional form, but uses another form as an external cultural influence. Based on preliminary data collected, in Cakranegara territory there is a mandir as a place for carrying out Hindu religious activities.

Regarding the description above, this research focuses on four aspects related to the spatial dynamics of Hindu family holy place that indicate new findings in this study. First, the construction of the sanctuary area in the Hindu family does not fully use spatial placement in accordance with the direction of the purity of the compass. Secondly, not all of the construction of the sanctuary area in the Hindu family is in accordance with the Asta Kosala Kosala manuscript Guidelines. Third, the place of the holy place at Hindu family is not standard in the form of sanggah Imerajan but has adapted to external culture. Fourth, the number of pelinggih (shrine buildings) appearing to have a tendency to experience a reduction, especially in the area of the yard which is relatively narrow Hindu religious activity. Departing from this hope, the ability to built can be developed. These four aspects indicate the gap between the construction of Hindu family holy place that have been running since the historical period with the trends that have occurred lately, especially entering the era of modernization. 


\section{Research methods}

This research was designed in the type of interpretive qualitative research. With regard to its orientation, this research plan applies a descriptive case study strategy. This research was procedurally carried out through systemic stages. First, preliminary observations to see phenomena related to the focus of research, especially those relating to dynamics in the spatial order of the construction of Hindu family holy place. Second, the data obtained from the initial observations are then set forth in a proposal to conduct a research plan. Third, all matters relating to research activities are prepared, including the preparation of research permits. Fourth, carry out field data collection in accordance with established data collection techniques. Fifth, conduct data analysis in accordance with established data analysis techniques. Sixth, conduct research seminars and formulate results in the form of research reports.

The descriptive case study in this research examines socio-religious phenomena related to the implementation of Hinduism in the life of the people which gives rise to diverse interpretations. Hindu family holy place as part of the actualization of Hindu teachings in their manifestations are always adjusted to the dynamics and development of civilization. Based on this phenomenon the dynamics in the construction of a holy place in field of Hindu family in the research location in accordance with the urgency of this research as a case study. Referring to Yin (2004: 4) case studies provide opportunities for researchers to maintain the holistic and meaningful characteristics of real life events. Therefore the implementation of this research seeks to uncover the real events of Hindu life, especially in the domain of social environment change.

Regarding the approach used, in this study using the socioreligiosity approach. The data presented in this study are mostly ex post facto approaches as referring to Nazir (1999: 65) that this approach model in principle obtains data in data collection techniques after all events take place. This study has no artificial symptoms. The data collected is as it is in the research location. In line with the above phenomenon, this study seeks to analyze social-religious phenomena relating to the dynamics of idiology traditionality at holy place in Hindu family in the Cakranegara territory, Mataram City, which position a number of past events (both tangible and intangible) that are used as research data sources then analyzed with established analysis techniques.

The type of data needed in this study is in the form of qualitative data supported by data in the form of numeric. Qualitative data needed in this research is in the form of expressions, words, ideas or ideas, opinions, and notes relating to the problem under study. The data is partly collected from the results of interviews and field observations. Qualitative data sources, as emphasized by Suprayogo and Tobroni (2001: 162-163), place the data source as a subject that has an important 
position. Consequently, the accuracy of choosing and determining the source of data will determine the wealth of data obtained.

The data source of this study consisted of two, namely primary data sources and secondary sources. Primary data sources have been obtained directly from informants and religious social activities. The data source is in the form of informants are used in this study because the informants are the source of information and at the same time act as an actor who determines the success of the research based on the information provided. Source of event data (activity) is needed in this research, especially in observing events or activities related to research problems. This data source as emphasized by (Suprayogo and Tobroni 2001: 162-163) is also used to cross check verbal information provided by informants as the subject under study.

Secondary data sources obtained indirectly from the main source, but obtained through the study of documents, especially textual sources in the form of ancient books and manuscripts, such as papyrus both original and that have been transliterated. Secondary data is also supported by a number of archives from various agencies, statistical data, and monographs. Documentary sources (archives) as written material or objects related to certain events or activities in the past are used because they relate to the need for research data.

Research data collection techniques consist of observation, interviews, and document studies. Researchers involve themselves in making observations, especially in relation to activities that are laden with symbolic phenomena and at the same time accommodate the interests of groups at the research location. Observations focused on events (activities) needed in this study, especially those relating to the dynamics in the spatial sanctuary of Hindu families in Cakranegara territory, Mataram City. Unstructured interview techniques in accordance with those recommended by Fontana and Frey (2009: 507) that unstructured interviews (unstructured interviews) provide more space than other types of interviews. Fontana and Frey cited Malinowski who argued that unstructured interviews were used to understand the complexity of the behavior of community members without a priori categories that could limit the wealth of data that could be obtained. In an effort to explore the data in this study unstructured interview techniques are very effective in digging in-depth data because they are based on the reason of the researchers' relationship with the informants to be maintained. Secondary data collected in this study were taken through document data. The secondary data obtained were further analyzed using document studies. This study used document studies as a source of secondary data. The source documents used in this study are other supplementary documents in the form of documents from various agencies, literature, journals, statistics, and other relevant references. Secondary data obtained from documentary sources are then analyzed according to the data analysis 
technique used. Document study technique according to Nawawi (1983: 139) is a way of collecting data through written relics in the form of archives, while also using literature studies. The archives were obtained from a number of sources, both institutional and non-institutional. Literature study in the form of books, opinions, theories, propositions / laws and others related to research problems

Data analysis techniques are carried out through classification, reduction, and interpretation. Data classification is the stage of grouping data obtained based on data collection techniques during data mining in the field. According to Bogdan and Biklen (in Suprayogo and Tobroni, 2001: 193), at the end of the analysis during data collection the objectives of data collection are determined. Data collected both from informants, situations, and documents were determined. Data classification in this study is done by grouping data consisting of: (1) data obtained from observations, (2) data obtained from interviews, and (3) data obtained from the results of documentation studies. This treatment is very important to facilitate the subsequent checking and analysis. The data obtained in this study after further classification is done reduction. Data reduction according to Miles and Huberman (in Suprayogo and Tobroni, 2001: 193) is a process of selecting, focusing on simplifying, abstracting, and transforming rough data, which arises from field notes. Data reduction continues throughout the study. Before the data is actually collected, anticipation of the reduction is already apparent when the research decides the conceptual framework of the research area, the research problem, and the data collection approach chosen. Researchers do data reduction at the same time during data mining in the field. Reduction of data in this study through the process of selecting, focusing and simplifying rough data taken from the author's notes during data collection in the field. Actually the reduction is not only carried out after all data is obtained, but continues throughout the research. Interpretation is carried out during the research process starting from data retrieval which aims to obtain meaning, specifically related to symbolic activities. Referring to Geertz (1992: 34-35) that the view of how theory functions in an interpretive science suggests that the distinction, which is relative in any case, that appears in experimental or observational sciences, between description and explanation here appears as distinction, which even more relative between writing and specification, that is, between writing the meaning of specific social actions for the actors whose actions are written, and stated, as explicitly as can be attempted, what the knowledge then shows about the community where it is found, and more than that about social life as it is. 
Website Jurnal : https://ejournal.iahntp.ac.id/index.php/satya-widya/index

DOI: https://doi.org/10.33363/swjsa.v3i1 Juni.435

\section{Results of Reseach}

\subsection{The Dynamics of Position Sacred Area for Building Holy Place in Hindus Families}

Schematic dynamics of idiology traditionally at holy place of Hindu family in Cakranegara territory, Mataram City, West Nusa Tenggara, Indonesia represent cultural dynamics in the implementation of Hinduism. Balinese culture in the Hindu community in Lombok, especially in physical form (artifacts) such as the existence of a shrine in a dynamic context, is still able to demonstrate its existence. Despite the existence of traditional Balinese-style building architecture as conceived hundreds of years ago, it is still culturally able to adapt to environmental conditions, even more so in responding to social changes as the implications of modernization and globalization.

Regarding the Hindu family's holy place in Cakranegara territory, it is traditionally called merajan or sanggah, which has differences that are not essential. Based on the narrative put forward by Pandita Mpu Jaya Daksa Acarya Natha (Hindu priest-an informant) that the use of the term merajan is arguably limited to sor singgih basa or alus or roughly in using language. Generally merajan is a term for Hindu family holy place in the family of triwangsa, while sanggah is used as a term for mentioning family holy place in Hindu groups outside the tri wangsa. Synergize with the above terms, referring to Sura et al. (1994: 63) that the place of worship for families who are in one family unit of the household to the extended family in the form of objections or examination is limited to the difference in mentioning. Certain families refer to the family holy place has been called merajan, in some families call it a sanggah. For a small family place of worship, it is called a merajan alit, whereas for a place of worship that is called a merajan agung or sanggah gede. Merajan Agung or sanggah gede is also referred to as merajan or sanggah kawitan or dadia or panti. Pelinggih is mainly in the form of gedong rong telu (sacred building with three small cubicles).

Judging from the spatial structuring dimension, which is related to the placement of the merajan/sanggah position as a pengulun karang (upstream home), both the merajan and the sanggah owned by Hindus in Cakranegara territory are traditionally positioned in the direction believed to have purity values such as the direction of the kaja (north), kangin (east), or kaja kangin (northeast) in the area of the home yard. The choice of the position above as stated by the Pedanda Sebali Kenatan (an informant) is based on the belief system that all three positions have vibrational purity. The direction of the kaja (north) was chosen as a position to build a holy place in the form of a sanggah / merajan based on the belief that the direction of the kaja (north) as a place of giri (mountain), that is, as a symbol of Lord Siwa holy place. Referring to the siwatattwa concept, Siwa is the ruler of the pengider (all direction) so that he is God. 
Synergy with the phenomenon above the relationship between the direction of kaja (north) and the mountain greatly influences the belief of Hindus in determining the spatial development of merajan/sanggah as a place that in the evaluative symbol dimension has purity. The direction of kaja (north) as a pengulun karang, especially in the Cakranegara territory region is in harmony with the contents of the chronicle, mythology, and purana as stated by Suandra (1997: 3-4) that according to the contents of the chronicles and mythology, the mountains in Java originated from Mount Mahameru in India. Likewise, it is also mentioned in chronicles, the purana that Mount Agung on the island of Bali which is also called Mount Toh Langkir originates from Mount Mahameru in India. These mountains are considered sacred places. Based on this phenomenon, it is not surprising that Hindus in Indonesia worship or worship facing the mountains.

The direction of the wind of kangin (east) was chosen by Hindus in the Caranegara territory as a place to establish a sacred place in a family field based on the belief that the direction was the position of the rising sun. Hindu teachings highly respect the sun as the Sun God, namely "Raditya" as the source of life on earth. The concept of siwatattwa as a source of Hindu teachings that has the character of Siwaistik teaches that the sun is respected and glorified as Siwa Raditya. Even in the tradition of Hindu worship in Lombok, Dewa Surya Raditya was glorified in the mantram (holy chanting) of five prayers in the second stanza. The mantram carries the meaning of observing the presence of the solar God Raditya as a witness to the world and as a source of life for beings.

The dimensions of the spatial order that uses the direction of kangin (east) as a position to establish merajan/sanggah as a symbol of glorifying the god Surya Raditya are associated with historical factors having strong references. This phenomenon is in line with the sect system that had developed during the Ancient Bali era in realizing Hindu teachings, colored by the existence of nine sects citing Goris (2008: 1-21) who wrote how the dynamics of the sects in Bali in realizing a unified view. Goris describes the nine sects that existed in Bali during the era of the Ancient Balinese kingdom, including: Çiwa-Sidhānta, Pāçupata, Bhairawa, Weșnawa, Bodha or Sogata, Brāhmaṇa, Rṣi, Sora or Sūrya worshipers, and Gaṇapatya or worshipers of Dewa Ganeça. Regarding worship of Surya Raditya, Nurkancana (1998: 135) argues that the Sora Sect is a sect that worships Surya as the main deity. Regarding the worship system, the Suryasewana conducted by the priests in Bali is the influence of the Sora Sect.

The choice of position to build a sacred place in the Hindu family in the form of merajan/sanggah is the meeting of the direction of the kaja (north) with kangin (east) which is termed the kaja kangin (northeast) direction. In synergy with the description above, the direction of the kaja kangin (northeast) is believed to have holiness because it is a blend of the two cardinal directions that has holiness. 
Judging from the concept of pengider-ider (naming traditional Balinese directions) according to the teachings of siwatattwa the direction of the direction of the kaja kangin (northeast) is the status of Lord Sambu. The position of merajan/sanggah in the direction of the northeastern direction point as written in the manuscript of Asta Kosala Kosala (quoted from Pulasari, 2007: 15) is called purwaning karang. If it is not possible to place merajan/sanggah in the direction of kangin, such as citing the expression Anom (2009: 2) for some reason, in the direction of kajaikangin (northeast) it is inadequate in terms of cleanliness such as being exposed to neighboring streams, then the place can be elevated to a place merajan or sanggah.

The phenomenon of the placement of holy place by referring to the three directions of the compass as mentioned above, besides being used to place holy place in the family environment, but also in positioning the sacred buildings which have a greater level such as temples. Citing Ngurah et al. (1998: 177) that the location of the temple shrine according to Hindu beliefs is upstream, based on the direction of the sunrise or the location of the mountain. The sunrise or the location of the mountain is seen as a sacred direction, because both natural resources are created by God as the source of life for all beings. For Bali the upstream direction is east and north or in the northeast corner.

The entry of external influences, especially the presence of modernization and the inclusion of the influence of ideological groups of spirituality followers, are determinants of the dynamics in the spatial order in the Cakranegara territory region, Mataram City. The influence of modernization is mainly in the process of commodification of a number of aspects of Hindu life in the Cakranegara territory. The process of commodification is the trigger for the formation of a consumer society which has implications for modern lifestyles. Synergizing with this phenomenon, the lands around Cakranegara territory area were converted into many functions, as agricultural land was initially converted into a residential area. The implication of this event is that land ownership has become increasingly narrow, including where their settlements have also experienced a shift in spatial planning.

The narrowing of land in building karang paumahan has implications for the dynamics in determining the spatial area of housing, including in relation to the determination of the position of a holy place in the family environment. Lately, the position of holy place among Hindu families in accordance with the results of field observations is not limited to following traditional patterns such as choosing the direction of kaja (north), kangin (east), or kaja kangin (northeast) which are believed to have holiness in the dimensions of evaluative symbols. A number of Hindus in the Cakranegara territory region position a sacred place in the family environment in the middle of the yard. Sacred places in the form of merajan/sanggah for Hindus who have relatively narrow land are often positioned at the top, especially those who have houses with more than one floor. 
Based on the above phenomenon in the arrangement of holy place in the Hindu family does not always use the traditional concept of positioning the holy place in the form of a refutation on the spatial upstream in accordance with the pengider concept, which uses the direction as a standard guide. Based on its position on the top floor, the shrine is more likely to use the akasa-prtiwi concept. This is in accordance with the results of an interview conducted with Ida Pedanda Sebali Kenatan (an informant), which basically states that the objection placed in a terraced house is an implementation of the akasa-perwiwi concept. To maintain the sanctity of the sanggah on the upper floor, the lower level should not be flushed (an unholy condition) such as a toilet. If possible under objection, space should be made that has purity values such as a place to study.

On another dimension, the placement of Hindu family holy place in the form of sanggah on the upper floor of a house that has multi-storey buildings as far as possible is avoided. This is as narrated by I Gusti Ngurah Sunarta (an informant) which in essence states that the placement of the protest on the top floor should be avoided as far as possible because it is not good for building harmony in the family e. There are some families who place objections on the top floor of a house whose family conditions are not harmonious, such as children with parents who are not suitable. That is because the objections are not on pertiwi (the ground). Rationally, the placement of the refutation on the top floor of the building has a reason, especially if there are natural disasters such as earthquakes and hurricanes automatically those who are worshiping will not be able to fully concentrate, it is different if the objections below they are not too concerned about it so can be more concentrated.

With regard to the placement of the sanggah position in the middle of the reef housing (the area of the yard) is inseparable from the belief system adopted by the people. This phenomenon occurs as in the protest owned by I Wayan Mandra, located on Jl. Terusan Angsoka 2 No. 5 Taman Bogor Mataram. Based on the narrative delivered by the owner, the placement of the sanggah in the middle of the plot area is backed by instructions given by the pedanda (priests). The construction of the protest in the yard of this house in the eighties. This place used to be a land owned by Ida Anak Agung (The King of Karangasem Kingdom in Lombok). This yard was once a park called "Taman Bogor". The history of naming the Taman Bogor regarding the exile of Ida Anak Agung to Bogor by the Dutch colonial. His arrival from exile in Bogor made the Taman Bogor.

Based on observations, in terms of the time of manufacture the objections are relatively new. The location of the sanggah is in the main part of the mandala (division of space according to Balinese tradition) and is in the middle of the yard. Outside the sanggah is the middle area of the mandala, that is in the southern position there is a building where dancing exercises are carried out, in the west it is 
a spatial empty a few meters as the main boundary of the mandala and the middle of the mandala and then there is the building of the house where the owner lives. The northern space of the sanggah is also an empty space a few meters and then connected by a residential building. The spatial to the east of the sanggah is also a few meters of empty space which is connected to the house where the family lives. Empty space that is outside the main spatial mandala is natah (yard) which is filled with plants that are beneficial to the family such as flowering plants, medicinal plants, and ornamental plants.

Structuring the house yard as described above in terms of dimensions still follow the traditional spatial layout. This phenomenon is indicated by the arrangement of space into three parts, namely utama mandala (main area), madya mandala (middle area), and nista mandala (profane area). The utama mandala is positioned as a pengulun karang (upstream of the yard) which is built a place of family worship in the form of sanggah. Spatial of madya mandala is placed buildings that are used as a place of family activities such as a place to learn to dance, bedrooms, kitchens, and family meeting places. Spatial of nista mandala is a profane area, which is positioned to place toilets, clotheslines, and others.

Regarding this phenomenon, traditional concepts that position the direction of the kaja (north), kangin (east), and kaja kangin (northeast) as pengulun karang (upstream home) are not standard and rigid. The choice of middle position as a place of objection if it is associated with Siwatattwa teachings has the same concept. Siwatattwa teachings position the central space as a sthana (holy place) of Lord Siwa, that is, as the controlling center of the universe. The essence of the teachings of Siwatattwa, especially with regard to the concept of God, believes in Dewa Siwa as the ruler of the Bhuana Agung (universe). Dewa Wisnu in the north, Dewad Sambu in the northeast, Dewa Iḉwara in the east, Dewa Mahesora in the southeast, Dewa Brahma in the south, Dewa Rudra in the southwest, Dewa Mahadewa in the west, Dewa Sankara in the northwest are manifestations of Śiwa. In connection with this the position of the holy place in the middle of the area of the yard as an embodiment of the concept of Siwatattwa in the spatial dimension of the placement of Hindu family holy place.

Placement of Hindu family holy place in the form of merajan that is not right upstream, namely kaja (north) or kangin (east) or kaja kangin (northeast) are also found in the griya (family brahmana wangsa house). The spatial position of the family holy place in the form of merajan belongs to the family of Ida Bagus Putra Kaniten located at Jl. Salak no.17 Tohpati area, Cakranegara territory. Based on the results of field observations, it was found that there is a profane area located in the north (kaja) spatial merajan. The profane area is spatial which is used as a chicken farm. The profane spatial in the north (kaja) merajan as a family sanctuary in accordance with that narrated by Ida Wayan Asta (an informant) revealed that 
the merajan was built by his parents who had died and in his lifetime he was a pedanda (Hindu priest). According to the informant above, it is estimated that the profane spatial located in the upper reaches of the griya yard is estimated to be the land obtained after the merajan was built. Since the merajan was built earlier than the acquisition of land to the north, there were no plans to move the holy place in the direction of the north ( $k a j a)$ and instead when the researchers observed the spatial location of the profane located next to it north merajan built a farmhouse in the form of a chicken coop.

Synergizing with the above phenomenon, the spatial profane in the direction of kaja (north) Hindu family holy place is also found in Ida Ayu Nyoman Suryawati's farm located in Gang Salak 2 in Tohpati, North Cakranegara territory. The profane spatial located in the upper part of the farmyard is in accordance with the results of field observations containing plantations. Based on the narrative expressed by Ida Ayu Nyoman Suryawati, the profane spatial in the form of plantation land in the upstream direction of the yard is estimated to be motivated by the northern boundary of the original plot, indeed because it is in the merajan, but because there is a new land that was obtained it might be from buying results or additional inheritance from their accidental ancestors. Located in the north merajan, causing the yard to become more widespread towards the north. Changes in the area of the yard to the north cause the position of the family sanctuary as if shifting towards the south. In connection with this phenomenon, the family's holy place is not exactly in the upstream direction of the yard or it is not located in the right direction (north) of the yard. The concept of spatial placement for merajan was initially in accordance with the traditional literary and spatial concepts inherited, but due to the expansion of the land to the north, it was as if there was a shift in the spatial development in the griya (priest house).

\subsection{The Dynamics of the Spatial Size of the Sacred Buildings}

The dynamics of traditionality's ideology in the construction of holy place in Hindu families are also influenced by modernization. The influence of modernization is a determinant in triggering dynamics in determining the spatial size of the construction of holy place in the Hindu family. In connection with this phenomenon in building a holy place in the Hindu family tends to experience a shift in determining the dimensions of space. The relatively high sale value of land is a fundamental reason for rearranging residential buildings in the yard area. In this regard the building size no longer fully uses the procedures mandated in religious literature. Some Hindus in building residential houses tend to no longer use traditional measurements according to literature, but instead use modern-style measurements. 
Describe the spatial size of the building of a holy place in the Hindu family in the Cakranegara territory traditionally uses sastra drsta (instructions from sacred literature). In connection with these conditions, Hindus who build sacred places in the family use literary sources such as asta kosala kosali manuscript which have been commonly used as guidelines. Asta kosala kosali manuscript contains building procedures, both in the form of holy place and dwellings such as houses, halls, kitchens, rice storage areas, and other buildings in the family environment.

Based on the results of interviews conducted with a number of residential owners whose spatial area has experienced a reduction, it was revealed that the most important reason as a cause was because of the relatively small ownership of the land. The reason is a determinant in determining the spatial sanctuary that changes. Synergizing with this phenomenon, Nurkancana (1998: 163-164) revealed that if circumstances were not possible, (the yard was too narrow or lived in a flat, or in the contract place), then there were several alternatives that could be taken. The first alternative, making a place of worship in the form of plangkiran. Plangkiran can be placed in the bedroom, in the guest room, in the family room, or in a special room that is used as a holy room. The second alternative, make a place of worship in the form of pelanggahan (a form of worship found in some early Balinese people). The equipment can also be placed in the bedroom, in the guest room, in the family room or in a special room (in the sacred room). The third alternative is to make a place of worship made of wood shaped like punden berundag. Undag (top level) to worship God, the second undag to worship the gods and ancestors. The lowest undag can be made to resemble a sideboard, so it can be used to store ceremonial tools. Punden berundag can also be placed in the bedroom, in the guest room, in the family room, or in a special room (sacred room). The fourth alternative is no need to make a place of worship specifically. Worship can be performed on a sideboard, or on a table, or on a floor lined with purified cloth/mats/rugs.

Based on the narration above, in building a holy place in the family environment adapted to the situation and conditions in the yard. If the area of the yard provides an opportunity to build a holy place in the form of merajan/sanggah, it would be nice to build a place of worship in the form of merajansanggah, but if not possible then the four alternatives above can be chosen one. Likewise, building merajan/sanggah should use the appropriate development procedures wherever possible, in this case it can take the level of nista (lowest level), madya (middle level), and utama (main level) that cites Suandra's (1997: 15) terminology as terming the building of pewanguning sanggar parhyangan (build a sanctified place).

\subsection{The Dynamics of the Spatial Form of the Holy Place in Hindu Family Environments}


Describe the dynamics in the form of holy place in the Hindu family in the Cakranegara territory region in accordance with data collected in the field linked to the spatial use of holy place in addition to merajan/sanggah. Based on field observations, there are a number of Hindus who already have merajan/sanggah also have a sanctified place whose spatial is indoors. The term used to mention this sanctified place is "kamar suci" (holy room). Those who have a "kamar suci" (holy room) besides the holy place in the form of merajan/sanggah are generally among the followers of spirituality groups. In fact, according to one of the owners of the "kamar suci" (holy room) that religious activities such as worshiping are more often done in the "kamar suci" (holy room) compared to being refuted as revealed in an interview passage with I Made Sujana (an informant) which in essence revealed that in addition to having had a sanggah also made "kamar suci"(holy room). In carrying out activities such as praying, meditation, yoga, or asking for guidance when he need guidance, he is more often done in the "kamar suci" (holy room) than in sanggah/merajan. The reason is because when he do spiritual activities in the "kamar suci" (holy room) he is more often present and give instructions or provide answers to what he ask. The objections in our house are usually used to carry out religious activities on certain days, but we can function the "kamar suci" (holy room) at any time as needed.

The beliefs of a number of Hindus as narrated above, especially those related to carrying out spiritual activities in the "kamar suci" are generally carried out because they are backed up by reasons of family circumstances and conditions such as the ownership of relatively narrow housing areas. Synergizing with this phenomenon, Nurkancana (1998: 163) also stressed that carrying out spiritual activities such as worshiping in the home environment in the form of a "kamar suci" is an alternative for Hindus if the home page is inadequate for erection in the form of worship.

Based on field observations, the "kamar suci" owned by I Made Sujana is equipped with symbols commonly used by Hindus, both in India and in Bali. The symbols are categorized into three, namely symbols in the form of images, in the form of statues, and in the form of pelangkiran (a small shrine in the room). Symbols in the form of pictures contain paintings of ista dewata (certain gods worshiped), such as Dewa Śiwa, Dewa Ganesha, Dewi Durga, Dewio Sawitar, dasa bayu script symbols, yantra symbols and other symbols. Symbols in the form of sculptures such as the symbols of Dewa Brahma, Dewa Vishnu, Dewa Siwa, and other gods. The symbol of pelangkiran contains a place to ngelinggihan (put) holy water and other ceremonial facilities.

Based on the above phenomena, the construction of a "kamar suci" (sacred room) as a place of worship in the family environment in addition to the objections that it has become an indicator that there has been a dynamic at the level of the form 
of Hindu holy place. The dynamics as external influences, originating from groups of followers of Indian-style spirituality who come to Lombok lately. Based on observations in the field, Hindus in the Cakranegara territory who have a place of worship in the form of "kamar suci" (holy room) are those who take part as a spirituality group such as the Sai Studi Group (SSG).

Synergizing with the above phenomenon, the dynamics that occur at the meso level, namely the wider scope which involves a number of Hindu families in the Cakranegara territory, is the creation of a holy place in the form of a mandir. Listening to the historical background, the sacred place of the mandir is a form of place of worship that is categorized as relatively new. In terms of its shape, mandir is a form of holy place as an influence of external culture, especially Indian culture.

The symbols used in the place of worship as above will be meaningful if those who worship are accompanied by sraddha (beliefs) and bhakti (feelings of respect) in implementing these beliefs. Synergizing with this symbolic phenomenon Titib (2001) stressed that an object would be a very sacred symbol if the people worship Him with sincere devotions and devotions. Objects that are used as sacred symbols will contain high spiritual power like an iron which is held close to a magnet, the longer it is brought closer, the longer the iron will also contain a magnet. Dealing with this phenomenon a certain statue or symbol will be lived and worshiped steadily by its worshipers.

\subsection{Dynamics in the Number of Pelinggih in Hindu Family Field}

The dynamics in the form of holy place in the Hindu family in the Cakranegara territory are not only indicated by changes in the physical form of the place of worship, there is also a change in the level of holy place found in the spatial sanctuary. Based on interviews with informants it was revealed that the number of holy sites in the Hindu family environment in the Cakranegara territory has traditionally varied. There are families who build pelinggih (physical worship buildings) of three, there are five, there are seven, and there are even eleven. The quantity or number of pelinggih in Hindu family holy place cannot be compared and adjusted to the concept referred.

In synergy with the above, regarding the number of pelinggih in Hindu literature varies. Referring to Anom (2009: 156-157) that if permanent residence at least makes the smallest place of worship (nista or lowest level) in the form of a tri lingga consisting of rong tiga, pengelurah, and taksu. The construction of holy places in the family at the middle level makes panca lingga consisting of rong tiga, pengrurah, taksu, gedong sari, and peliksari. Whereas at the tingkat utama (main level), they make sapta lingga consisting of rong tiga, pengrurah, taksu, gedong sari, peliksari, gedong catu, and menjangan seluang. Pelinggih which is at utamaning utama (above the main level) makes eka dasa lingga (merajan ageng) 
consist of rong tiga, pengrurah, taksu, gedong sari, peliksari, gedong catu, menjangan seluang pesaren, limas sari, padma, and tugu.

Synergizing with the phenomenon as mentioned above, the reduction in the number of pelinggih in holy places at Hindu family was also approved by I Gusti Ngurah Sunarta, which in essence revealed that the construction of pelinggih in the yard of the house did not need too much. If you want to worship can be symbolized by the form of upakara (means of ceremony) or banten (offerings). Pelinggih can be only one form and if you want to realize the various symbols of God or ancestral spirits can be realized by making upakara (means of ceremony).

In line with the above concept, worship performed in a sacred place according to the teachings of Hinduism is inseparable from the aspects of manifestation Ida Sang Hyang Widhi Wasa (God Almighty). With regard to this phenomenon Sura et al. (1994:62) argues that to worship the Almighty God in various aspects, His manifestation was built places of worship that are always purified. Worshiping the existence of God which is essentially unlimited and without form is furthermore given limits and form in the interests of worship. Aspects that are desired to be called Ista Dewata (the symbol of God that is about to be presented).

On another dimension, there is a Hindu family holy place in the form of a sanggah in which pelinggih is built in accordance with the concept of mandala (division of space according to Hinduism). Based on the results of observations of the objections in I Wayan Mandra's house located on Jl. Angsoka Canal 2 No. 5 Taman Bogor Mataram there are three pelinggih (sacred buildings) in the utama (main area) of the mandala. Pelinggih are gedong taksu, rong tiga and ngelurah. Rong tiga is the main pelinggih because in that place Bhatara Siwa is distributed with manifestation Tri Murti and ancestral spirits. Rong tiga characterizes the Hindu family's place of worship which is often also referred to as sanggah kamulan. This phenomenon is as stated by Wikarman (1998: 13) that what is worshiped in sanggah kamulan is essentially God/Ida Sang Hyang Widhi, both as the Sang Hyang Tri atma, who as atma (the spirit) of the universe with its contents and the devine are is Dewa Brahma, Dewa Wishnu, and Dewa Iswara, which are aspects of God in the horizontal and Śiva, Sada Siva, Parama Śiva, aspects of God in the form of vertical (Tri Purusa). As Tri Purusa he is also called Guru Tiga. Because of the general also mentioned that isanggah kamulan is stana (place) of Bhatara Guru/Hyang Guru.

Regarding the existence of rong telu at Hindu follower in Lombok Island in general has not become uniformity. Such phenomena as narrated by Dewa Ketut Mertayasa (an informant) which in essence revealed that for a sacred place in the Hindu family there are already rong tiga and there are also those who do not. For Hindus who come from Nusa Penida generally they establish pelinggih in the form 
of rong dua. Pelinggih rong dua is essentially as a linggih (holy place) of Ardhanareswari symbolized by the aksara ang and ah which are placed in the position of kiwa (left) and tengen (right) which is a place to make marriage for mothers and fathers. Rong dua in relation to this as a place to holy place of Dewa Hyang.

Based on the narrative stated by the informant above, both pelinggih rong tiga and pelinggih roh dua are essentially sacred places to place ancestral holy spirits that have been purified through the pitra yadnya (cremation ceremony). The existence of rong dua as a place to visit ancestral holy spirits in other dimensions is less approved by a Hindu cleric namely Pinandita Ida Ketut Widja. According to the informant, rong dua is not in accordance with the rules contained in literature because ancestral spirits who have amor ring acintya (already in the world of gods) should be distributed in rong telu. The existence of the ancestral holy spirit has become Ida Hyang, so a place in the form of kemulan should be made.

The narrative put forward by Pinandita Ida Ketut Widja as above implies that the practice of religion in the lives of Hindus in Lombok, especially in the Cakranegara territory relating to the making of a sacred place to enshrone the ancestral holy spirits that have become atma sidha dewata should be adapted to Hindu religious literature. besides that, it must also be adjusted to the procedures for building ancestral sacred places that have become Ida Hyang in accordance with the traditions that have been operating in Lombok as inherited from their predecessors. Listening to the expression expressed ideally should indeed be carried out as a form of a sense of devotion before the ancestors. Nevertheless, it is also undeniable that there has been a change in the sociocultural order to be a determinant in realizing the dynamics in the implementation of Hinduism, including in determining the construction of pelinggih in a spatial family sanctuary.

\section{Discussion of Research Results}

Based on the exposure to the above research results, the dynamics in building of the Hindu family's holy place in the Cakranegara territory, Mataram City are categorized into four classifications. These four aspects represent new findings in this study. Firstly, the placement of holy place tends to no longer apply traditional concepts. Secondly, the spatial size in the construction of holy place at Hindu family field is no longer fixed on traditionally applied spatial measures but is adjusted to the situation and condition of the karang paumahan (the area of the yard). Thirdly, in terms of the shrine of the holy place adapted to the inclusion of external culture. Fourthly, related to the number of pelinggih (shrine buildings) tended to experience a reduction, especially in the relatively small area of the new home yard. The following four dynamics are analyzed. 
Firstly, relating to changes in position in the construction of holy place in Hindu families. synergize with research results, the dynamic of spatial position in building holy place at the Hindu family field in Cakranegara territory, focused on the tendency that leads to changes in the layout of the shrine in the spatial dimension in the area of the family yard. Based on the results of interviews conducted with I Gusti Ngurah Sunarta (an informant), it was revealed that historically the holy place at the Hindu family field in the Cakranegara territory has similarities with Hindus in Bali. The similarity is mainly in determining the spatial sanctuary in the form of merajan/sanggah in the yard of the house. Both merajan and sanggah occupy luan position, that is, the position considered as upstream of the yard. Citing the idea of Wikarman (1998:1) that merajan/sanggah placed on the hick or upstream of the yard so that it is referred to as a pengulun karang. Sanggah is a sacred place in the family field which cites the writing of Tim Penyusun (2009:12) as a place that serves to worship "Atma Sidha Dewata."

The existence of traditional Balinese buildings by examining the historical background, as conceptualized by a number of architectural figures starting from the era of the Ancient Balinese Kingdom, made a major contribution to the structuring of cultural and religious systems. In connection with this phenomenon, Wijayananda (2004: 1-2) stressed that the existence of building culture inherited in the popular and rapidly developing Hindu tradition on the island of Bali cannot be separated from the great architect Kebo Iwa (during the Bali Aga) and Mpu Kuturan as a companion of King Anak Wungsu who ruled Bali in the $11^{\text {th }}$ century, who inherited many theories of architecture, customs, and religion. After the Aryans came to power in Bali during the reign of Dalem Waturenggong around the $14^{\text {th }}$ century Dang Hyang Nirartha also acted as a great architecture that colors the customs, religion, and development typology in Bali.

The asta kosali kosala manuscript is a guideline for building buildings in Balinese society. According to Widana (2011:7), the asta kosala kosali manuscript is the measurement of buildings accompanied by the incantations that are pronounced starting from starting the work that serves to purify the work. If this is not done it will get a hindrance, illness, and even death and impure mind Bhagawan Wiswakarma study architecture (dharmaning undagi) well. Conversely, if the rules of governance can be mastered, then the geometry of buildings can be utilized and can gain priority. Likewise in determining the size of a building determined by the literature of Kosala Kosala manuscript in order to obtain the good and avoid the evils that result.

In synergy with the above phenomenon, the traditional Balinese architecture inherited to date according to the views of other writers is inseparable from the system that was applied in prehistoric times. The phenomenon is mainly related to the construction of a place of worship among Hindus. According to Suandra's 
(1997: 3-5) that worship of pelinggih (a place to keep sacred symbols including transcendent symbols), which forms the background of beliefs underlying palinggihs in Bali, is a fusion of pre-ancient beliefs (before) Hinduism entered Bali and with Hindu culture in Java who entered Bali. Based on this phenomenon, there is a fusion of culture, where pelinggihs is symbolized as Ida Sang Sang Hyang Widhi Wasa, the Gods, Bhatara (holy spirit).

Based on the data above, there is a dynamic that occurs regarding the spatial placement of Hindu family holy place which are no longer exactly the same as those traditionally inherited. The existence of profane areas such as chicken coops and agricultural areas in the upstream area of the yard, namely in the direction of kaja (north) winds as expressed by their owners is based more on the consideration that there is no desire to relocate in a new spatial plan after being abandoned by their parents. They tend to preserve the yard layout as inherited by their parents. This tendency is based on the traditional system that in building buildings in the area of the yard from the beginning of the plan, it has standard guidelines in the form sikut (measurements in determining buildings). With regard to this phenomenon so that they no longer make changes in sikut they tend to preserve what has been passed down by their predecessors. Another consideration that has the opportunity to become a background not to move the family's holy place upstream (kaja) is the factor of financial availability. The relocation of the holy place to the upstream ( kaja) is identical to the relatively large funding needs, both concerning the physical construction and for financing the implementation of the ceremony which became its succession.

Secondly, dynamics in the size of the holy place in Hindu family accordance with the results of the above research. This reality is based on logical rationale. The main consideration in developing the number of pelinggih which tends to decrease, especially in new settlements is relatively small land area. This is consistent with the results of observations in the field found in residential plots. They tend to build family sanctuaries that are relatively small in size to fit in the size of the plot of land. Adjustment of pelinggih size in this context is very much influenced by modernization and the relatively high price of land.

The phenomenon related to the dynamics in determining the spatial extent of the construction of holy place in the Hindu family field as an implication of modernization as described above can be categorized as an indicator that leads to cultural transformation in the domain of religious practice. Modernization which has an impact on changes in determining the size in the construction of holy place seems to verify the opinion of Triguna (2009: iii) which states that the process of modernization is not limited only in the form of cultural transformation towards progress that resembles Western culture, but also with the dominance and hegemony of knowledge and technology The West towards traditional knowledge 
and technology. In this context traditional knowledge and technology are seen as something that is dysfunctional so that through this process there has been a systematic disappearance of traditional Balinese knowledge and technology. Even though traditional Balinese knowledge and technology is the commitment and moral validity of Balinese.

Thirdly, Related to the dynamics in the physical form of Hindu shrines there is an ideology that affects so that there are some Hindus who no longer follow the tradition by default since the past. Placement of the sacred symbols of Hindu religion in the "kamar suci" (sacred rooms) in the Hindu family as described above is actually part of the aspect of the realization of religious teachings in the lives of the people. Refer to Titib (2001) that the form of symbols used in Hindu religious practice as a medium to get closer to God Almighty. In fact the symbols in Hindu religious life in terms of form and material vary greatly from simple materials to very complex materials as described in the Vedic scriptures and Hindu literature such as palm leaves in Bali. The form of statues or divine symbols in Hinduism is inseparable from the conception of the depiction of God Almighty according to the Vedic scriptures and other Hindu literature such as depictions such as humans, animals, half humans and half animals, plants, half humans and half grown- plants, celestial objects, letters and even various means of offering such as daksina and other ceremonial facilities.

Fourthly, Based on the research results, dynamics also occur in the quantity of pelinggih which are built. have rational and logical reasons related to the ideology and condition of the space in which to build a holy place. The ideological foundation that underlies this is in the form of how to interpret the text of Hindu teachings contextually. $\mathrm{n}$ this regard, they think deeply about the identity of the supernatural power that will be placed in the shrine to be built (for example: gods, ancestors, or other transcendent aspects). Synergizing with it is built in accordance with the identity of the supernatural power that will be placed, so that there are those who build padma pelinggih, there are those who build up pelinggih rong tiga, or others.

Regarding the existence of three rong in the Lombok region in general has not become uniformity. Such phenomena as narrated by Dewa Ketut Mertayasa (an informant) which in essence revealed that for a sacred place in the Hindu family field there are rong tiga and there are also those who do not. For Hindus who come from Nusa Penida generally they establish pelinggih in the form of rong dua. Pelinggih rong dua is essentially as a linggih (to place) "Ardhanareswari" symbolized by the characters ang and $a h$ which are placed in the position of the kiwa and tengen, which is the place for staying kawitan (ancestors) of mothers and fathers. Rong dua in relation to this as a place ngelinggihang (to stay) Dewa Hyang. 
Based on the narrative stated by the informant above, both pelinggih rong tiga and pelinggih rong dua are essentially sacred places to remove (exterminate) ancestral holy spirits that have been purified through the pitra yadnya ceremony. The existence of rong $d u a$ as a place to visit ancestral holy spirits in other dimensions is less approved by a Hindu saint, namely Pinandita Ida Ketut Widja (an informant). According to the informant, the rong dua was not in accordance with the rules contained in literature because the ancestral spirits who were already in the position amor ring Acintya (already in the gods' world) should be distributed in rong telu. The existence of the ancestral holy spirit has become "Ida Hyang", so a place in the form of kemulan should be made.

On the other hand, aspects of conditions of the space aspects of conditions that affect the dynamics in determining the size of pelinggih that will be made in relation to the availability of home yards. In this regard, the dynamics in determining the size in building a residential house also has implications for the procedures for building a sacred place in the family field. The relatively narrow land ownership becomes the determinant in reducing the spatial extent of the construction of holy place in the Hindu family. Synergy with the phenomenon of Hindus who live in the Cakranegara territory and its surroundings in building merajan/sanggah, its size is relatively narrow compared to the rules of spatial determination as mandated in religious literature. Reduction of the area of the construction of the holy place in the form of merajan/sanggah is done to the people who will build new settlements, especially those that have relatively narrow land.

The tendency to reduce the number of pelinggih for Hindus who have relatively narrow yards of land is actually contextual. Another reason used as a rationale in building the number of holy place in the Hindu family in the Cakranegara territory region is the concept of the Godhead. In connection with this phenomenon Nurkancana (1998:161-162) argues that the many holy place/holy place were erected, related to the concept of divinity adhered to by Hindus. If the concept of divinity is based on the teachings of advaita vedanta, then only one sacred building will be erected. Because ancestral spirits are atman which are essentially Brahman (God). Thus there is no need for a separation of places of worship for God and for ancestral spirits. If what is embraced is the concept of divinity according to the teachings of the dvaita vedanta which is combined with the ancestral belief system, then the number of sacred buildings that need to be erected in a family place of worship are three, namely (1) a sacred building for the worship of God, (2) a sacred building for worship the gods, and (3) sacred buildings to worship the spirits of the ancestors.

The teachings are as explicitly stated in manuscript of usana dewa and manuscript of gong wesi as quoted in the following section. 
"ring kamulan ngaran Ida Sang Hyang Atma, ring kamulan tengen bapa ngaran Sang Paramatma, ring kamulan kiwa ibu ngaran Sang Sivatma, ring kamulan tengah ngaran raganya, tu Brahma dadi meme bapa, meraga Sang Hyang Tuduh...." Meaning:

"On sanggah kemulan, He has the title Sang Hyang Atma, in the right room of kemulan the father's, his name is Sang Hyang Paramatma. In the left room of kemulan the mother, it is called Sivatma. In the centered room of kamulan, Brahma, became the purusa pradana, in the form of the Sang Hyang Tuduh or God of Predestination (Wikarman, 1998: 7).

In the manuscript of gong wesi found the following quote:

“....ngaran ira sang atma ring kamulan tengen bapanta, nga, Sang Paratma, ring kamulan kiwa ibunta, nga, Sang Sivatma, ring kamulan madya raganta, atma dari meme bapa ragane mantuk ring dalem dadi Sang Hyang Tunggal, nunggalang raga...."

Meaning:

"... His name is Sang Atma, in the right of room your father's, that is, Sang Paratma, in the left of room your mother's, that is Sang Sivatma, in the center of kamulan room is fused to be the one and only one unites form ..." (Wikarman, 1998: 8)

Synergizing with the above teaching, Bhatāa Śra is immanent and transcendent. immanent means meaning everywhere while transcendence means overcoming the human mind and senses. This condition is quoted from the Bhuanakośa manuscript ike the following quote

Śivas sarvagata sūkṣmah bhūtānām antarikșavāt, Acintya mahāgrhyante na indriyam parigrhyante

Bhațāra Śiwa sira wyāpaka, sira sūkșma tar keneng angên-angên, kadyangga ning ākāśa, tan kagrhita de ning manah mwang indriya.

Meaning:

\section{Bhuanakośa II. 16}

Bhațāra Śiwa permeates everything, $\mathrm{He}$ is inscrutable, it is like the sky, unreachable by the mind and senses.

The teachings of Śiwatawa as quoted from the Tim Penyusun (2000:31) teach that Bhațāra Śiwa permeates everything, is everywhere, encompasses everything. With regard to these conditions he is present in the mind and the senses, but the mind and the senses are unable to reach them. This means he overcomes the 
mind and the senses. Such is the existence of Bhatāara Śiwa in the immanent and transcendent aspects.

Departing from the above phenomenon, in the pelinggih rong tiga, Bhațāra Śiwa and His prabhawa (manifestation) were presented in the immanent aspect as mentioned above that on sanggah kamulan He held the title Sang Hyang Atma, in the right room of kamulan father's, his name was Sang Hyang Paramatma. In the left room of kamulan the mother, it is called Sivatma. In the centre room of kamulan, Brahma, became a purusa predana, in the form of the Sang Hyang Tuduh (God Who Fated). Furthermore it is also stated that his name is Sang Atma, in the right room of kamulan your father's, that is, Paratma, in the left room of kamulan your mother's, that is Sivatma, in the central room of kamulan is united into the single Sang Hyang Tunggal uniting all forms. That is the condition of Bhațāra Śiwa in both the immanent and transcendent aspects.

\section{Conclusion}

Based on the results of this study four conclusions can be formulated relating to the Dynamics of the Sacred Order Schematics in Hindu Families in the Cakranegara territory, Mataram City, West Nusa Tenggara Province, Indonesia. First, the dynamics in the position of space selection places a holy place that is no longer standard according to what was done in the past. Secondly, the dynamics in the spatial measurement in building a trigger place in a Hindu family environment are not fixed on the traditionally applied spatial layout. The space needed in the construction of holy place that are happening now tends to be distorted. The occurrence of this distortion is caused by adjusting to the spatial structure of the housing (home area) that tends to be distorted.

Third, the dynamics in the form of holy place that experience adaptation to outside cultural influences. The form of Hindu family holy place that previously used a traditional model in the form of sanggah for the Hindu community of jaba wangsa families and merajan for Hindus who came from a tri wangsa family with the influence of outside culture there are Hindu families who build holy place in the form of "kamar suci" (holy rooms). Sacred places that are used together that involve a combination of several families have built a mandir as a holy place. Development of mandir as a sacred place to carry out religious activities are generally those who pursue spirituality. Fourth, the dynamics in the number of pelinggih (sacred buildings) indicated by the tendency to reduce the number of pelinggih in the Hindu family. Reduction in the number of pelinggih occurs in families opening up new yards. In this regard, the number of pelinggih built in new settlements does not fully follow the pattern adopted by its predecessors. 
Dynamic Ideology Of Traditionality In Developing Holy Places At Hindus Family In Cakranegara

Territory Mataram City

I Wayan Ardhi Wirawan

\section{REFERENCES}

Anom, I.B. 2009.Tentang Membangun Mrajan. Denpasar: CV.Kayumas Agung

Althusser, Louis. 2004. Tentang Ideologi, Strukturalisme marxis, Psikoanalisis, Cultural studies. Terjemahan Olsy Vinoly Arnof, Yogyakarta dan Bandung: Jalasutra

Bourdieu, Pierre. 1991. Language and Symbolic Power. Edited and Introduced by John B. Thompson, Translated by Gino Raymond and Matthew Adamson, Great Britain: Polity Press

1990. The Logic of Practice. Translated by Richard Nice, California: Stanford University Press

Dwijendra, N.K.Acwin.2008. Arsitektur Bangunan Suci Hindu Berdasarkan Asta Kosala-Kosali, Denpasar: Udayana University Press

Fashri, Fauzi. 2007. Penyingkapan Kuasa Simbol; Apropriasi Reflektif Pemikiran Pierre Bourdieu. Yogyakarta: Juxtapose

Fontana, A. dan Frey, J.H. 2009. "Wawancara Seni Ilmu Pengetahuan" dalam buku Handbook of Qualitative Research. Editor: Denzin N.K. dan Lincoln Y.S. Terjemahan Dariyatno dkk. Yogyakarta: Pustaka Pelajar

Geertz, Clifford. 1992, Tafsir Kebudayaan. Terjemahan Fransisco Budi Hardiman. Yogyakarta: Kanisius

Kartini Kartono. 1990. Pengantar Metodologi Riset Sosial. Bandung: Mandar maju

-----. 1990. Pengantar Metodologi Penelitian Sosial. Bandung: Bandar Maju

Koentjaraningrat, 2003, Pengantar Antropologi I, Jakarta: Rineka Cipta

Kumbara, A.A. N. A. 2004. "Etnisitas dan Kebangkitan Kembali Politik Aliran pada Era Reformasi: Perspektif Teoritis". dalam Buku Politik Kebudayaan dan Identitas Etnik. Editor: I Wayan Ardika dan Dharma Putra. Denpasar: Fak. Sastra Unud dan Balimangsi Press

Mulyadi, Lalu, 2001, "Verifikasi spasial Permukiman Hindu Di Cakranegara territory Lombok Nusa tenggara Barat", Yogyakarta: Tesis UGM

Nawawi, Handari 1983, Metode Penelitian Bidang Sosial, Yogyakarta: Gajah Mada University Press

Ngurah, I G. M. dkk. 1998. Buku pendidikan Agama Hindu untuk Perguruan Tinggi. Surabaya: Paramita 
Website Jurnal : https://ejournal.iahntp.ac.id/index.php/satya-widya/index

DOI: https://doi.org/10.33363/swjsa.v3i1 Juni.435

Nurkancana, I Wayan, 1998, Menguak takbir Perkembangan Hindu, Denpasar: BPPals, D.L.,2001, Dekontruksi Kebenaran Kritik Tujuh Teori Agama, Terjemahan Inyiak Ridwan Muzir, M. Syukri, Yogyakarta: IRCiSoD

Piliang, Yasraf A. 2003. Hipersemiotika: Tafsir Cultural Studies atas Matinya Makna. Yogyakarta \& Bandung: Jalasutra

Sanderson, S.K.,2003, Makro Sosiologi, Terjemahan Farid Wajidi, S. Menno, Jakarta: PT Raja Grafindo Persada

Soebandi, Ktut. 1985. Berbakti Kepada Kawitan (leluhur) adalah Paramo Dharmah. Denpasar: Kayumas Agung

Suandra, I Made. 1997. Himpunan Ulap-Ulap Palinggih. Denpasar: Upada sastra

Suprayogo Iman dan Tobroni. 2001. Metodologi Penelitian Sosial-Agama. Bandung: Remaja Rosdakarya

Takwin, Bagus. 2009. Akar-Akar Ideologi: Pengantar Kajian Konsep Ideologi dari Plato Hingga Bourdieu. Yogyakarta: Jalasutra

Tim Penyusun. 2009. Pedoman Membangun Tempat Ibadah. Jakarta:Dirjen Bimas Hindu

Tim Penyusun. 2000. Siwatattwa. Denpasar: Pemprop Bali

Titib, I Made, 2003, Teologi Dan Simbol-Simbol Dalam Agama Hindu, Surabaya: Paramita

Triguna, I.B.Y. 2001. "Redifinisi Simbolisme Masyarakat Hindu Di Bali" Denpasar: Laporan Penelitian Unhi

2000. Teori Tentang Simbol. Denpasar: Widya Dharma

1994. "Pergeseran Dalam Pelaksanaan Agama: Menuju Tattwa" dalam Buku Dinamika masyarakat dan Kebudayaan Bali. Editor: I Gde Pitana. Denpasar : BP

2008. "Modal Budaya dalam Perspektif Teoritik dan Terapan". dalam Buku Kebudayaan dan Modal Budaya Bali dalam teropong Lokal, Nasional, Global. Editor IBG Yudha Triguna. Denpasar: Widya Dharma 
Dynamic Ideology Of Traditionality In Developing Holy Places At Hindus Family In Cakranegara Territory Mataram City

I Wayan Ardhi Wirawan

........2009. "Proteksi Pengetahuan dan Teknologi Tradisional Bali”. Kata Pengantar Buku Ngwangun Parhyangan Lan Paumahan. Denpasar Widya Dharma

Widana, I Gusti Ketut, 2001, Hindu Berkiblat Ke India? Dan Pertanyaan lain tentang Hindu, Denpasar: BP

Widana, I.B.G. 2011. Dharmaning Asta Kosala Kosali, Arsitektur Tradisional Bali. Denpasar: Dharma Putra

Wijayananda, Ida Pandita Mpu Jaya. 2004. Tata Letak Tanah dan Bangunan. Surabaya: Paramita

Wikarman, I N.S. 1998. Sanggah Kemulan, Fungsi dan Pengertiannya. Surabaya: Paramita

Wirawan, I Wayan A 2006. "Dinamika dalam Sistem Simbol Kegamaan pada Komunitas Hindu di Kota Mataram, Provinsi Nusa Tenggara Barat (Sebuah Kajian Budaya)". Denpasar: Tesis Kajian Budaya Unud.

Yin, Robert K. 2004. Studi Kasus, Desain \& Metode. Terjemahan Djauzi Mudzakir. Jakarta: PT Raja Grafindo Persada 